\title{
СОСТАВ ФЛЮИДНЫХ ВКЛЮЧЕНИЙ ПО КР-СПЕКТРАМ В ПАЛЕОЗОЙСКИХ КАРБОНАТНЫХ ПОРОДАХ СЕВЕРО-ОСТАНИНСКОГО МЕСТОРОЖДЕНИЯ, ЗАПАДНАЯ СИБИРЬ
}

\author{
Краснощекова Любовь Афанасьевна', \\ krasnl@tpu.ru
}

Гарсия Бальса Аура Самид',

garciaas@hw.tpu.ru

\author{
Белозёров Владимир Борисович', \\ belozerovvb@hw.tpu.ru \\ 1 Национальный исследовательский Томский политехнический университет, \\ Россия, 634050, г. Томск, пр. Ленина, 30.
}

\begin{abstract}
Актуальность исследования связана с возможностью обнаружения залежей углеводородов в карбонатных отложениях палеозоя Западной Сибири и увеличения нефтегазового потенциала региона.

Цель: определение с помощью спектроскопии комбинационного рассеяния состава газово-жидких включений в доломитизированных карбонатных породах Северо-Останинского нефтяного месторождения, что позволит уточнить информацию о составе флюида и условиях образования вторичных доломитов в известняках, в связи с приуроченностью к ним зон нефтегазонакопления.

Объект: карбонатные отложения кровельной части доюрского фундамента Северо-Останинской площади Западной Сибири. Методы: петрографический (кристаллооптический) анализ, спектроскопия комбинационного рассеяния (КР-спектроскопия или рамановская спектроскопия), люминесцентная микроскопия.

Результаты. Разрез скважин Северо-Останинского месторождения сложен органогенно-оолитовыми известняками, часто доломитизированными, и доломитами разной степени зернистости. Петрографическое изучение карбонатных пород позволило выделить основные фазы развития доломита в известняках: первичный пелитоморфный материал, слагающий матрицу пород совместно с кальцитом; вторичный кристаллический доломит, выполняющий трещины и образующий частично правильные ромбоэдрические кристаллы. С использованием метода рамановской спектроскопии удалось обнаружить в газово-жидких включениях вторичных кристаллов доломита спектры с пиками 1187, 1243, $1348 \mathrm{~cm}^{-1}$, типичными для кероген-содержащего органического вещества, и пиками 1525 и $1597 \mathrm{~cm}^{-1}$, характерными для разупорядоченного углеродсодержащего материала. Такие пики в

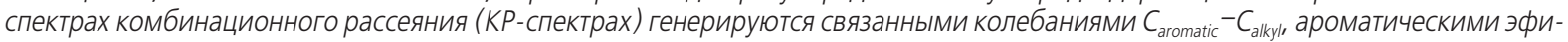
рами, С-С и С-Н в ароматических кольцах, установлены и соединения типа С=О. Наличие выявленных газовых фаз во флюидных включениях позволяет предположить, что формирование вторичного кристаллического агрегата доломита в карбонатных породах происходило из флюидного раствора, содержащего углеводородное вещество.
\end{abstract}

Ключевые слова:

Рамановская спектроскопия, флюидные включения, доюрские карбонатные породы, доломит, Западная Сибирь.

\section{Введение}

«Газово-жидкое включение - это включение в минерале, которое при комнатной температуре заполнено газом и/или жидкостью при отсутствии стекла. Кроме газа и жидкости они могут содержать кристаллы. В российской школе термин флюидные включения является синонимом газово-жидких включений.» [1. С. 37].

Флюидные включения (ФВ) представляют собой небольшие полости (1-50 микрон в диаметре), содержащие крошечные объемы жидкости и/или подвижных летучих фаз, захваченных минералами во время или после их роста, в которых давление и температура являются взаимозависимыми переменными [2].

Жидкая фаза может быть жидкой или парообразной и включать в себя водные растворы, летучие вещества, осажденные минералы, жидкие углеводороды. Эти жидкости могут подвергаться сложным химическим изменениям в зависимости от условий их существования и миграции.

Углеводородные включения являются прямыми образцами текучей среды, присутствующими во время их захвата, и могут содержать информацию о составе, условиях и последовательности преобразований (диа- и эпигенетических), происходящих в породах [3].

Для анализа состава флюидных включений разработаны многочисленные методы, которые могут быть разделены на две группы: валовые и индивидуальные анализы.

Валовые анализы основаны на быстром нагревании и механическом разрушении флюидных включений с анализом содержащегося во флюиде газа при помощи масс-спектрометрии (MS) и/или газовой хроматографии $(\mathrm{GC})[4,5]$.

Индивидуальные анализы газово-жидких (флюидных) обособлений, или микроанализы, включают в себя квадрупольные масс-анализаторы (QMS) [6], протон-индуцированное рентгеновское излучение (PIXE) [7], лазерную абляционную масс-спектрометрию с индуктивно-связанной плазмой (ЛА-ИСП-MC) (LA-ICP-MC) [8], рентгеновскую флуоресценцию синхротрона (SXRF) [9].

Валовые анализы разрушают тонкую минералогическую матрицу, необходимую для полного 
описания происхождения и истории изменений флюидов, потому что определяют только состав всех флюидные включений в образце, независимо от температуры захвата или смешивания флюидов [10]. С другой стороны, методы микроанализа представляют информацию о конкретных включениях, обычно в сочетании с подробными микротермометрическими данными, и требуют доступа к специализированному и дорогостоящему оборудованию.

К недеструктивным методам микроанализа газово-жидких включений в породах можно отнести инфракрасную микроскопию (ИК-спектроскопию с фурье-преобразованием) $[11,12]$, люминесцентную (флуоресцентную) спектроскопию [13] и спектроскопию комбинационного рассеяния (КР-спектроскопию, или рамановскую спектроскопию) [14-16].

При петрографических исследованиях применение рамановской спектроскопии позволяет определять не только минеральные компоненты, но и исследовать углеродсодержащие вещества в горных породах. Метод чувствителен к присутствию и структуре углеродных фаз, которые трудно охарактеризовать с помощью оптической микроскопии или электронно-лучевого микроанализа. $\mathrm{Me}$ тод комбинационного рассеяния использовался для оценки индекса термической зрелости разупорядоченного углеродистого материала и битума [17], керогена типа II [18]. Возможности применения метода рамановской спектроскопии и корреляция полученных КР-спектров с геохимическими свойствами органического вещества сланцевой нефти и газа (коэффициент отражения витринита (\% VRo) и пиролиза Rock-Eval (RE)) приведены в материалах исследования [19]. В работе [20] показаны примеры определения органического вещества, встречаемого даже в виде пленок на стенках включений, КР-спектроскопией, что позволило исследователям установить условия миграции вторичных растворов в породах.

Кроме того, рамановская спектроскопия, вопервых, не требует временных и материальных затрат для подготовки образца и, во-вторых, имеет размер лазерного пятна в пределах 1-2 мкм, что позволяет работать с небольшими включениями, в том числе в масштабе отдельных фаз в жидкостном включении [21].

Опубликованные результаты изучения природных флюидных включений в нефтеносных отложениях с использованием спектроскопии комбинационного рассеяния немногочисленны. Данные анализа естественных углеводородных флюидвключений в осадочных породах приведены в некоторых работах [22-27 и др.]. Одной из возможных причин ограниченного количества научных работ по теме исследований является появление лазерно-индуцированной флуоресценции флюидов, содержащихся во включениях (например, углеводородах), или их появление в минерале-хозяине (например, Fе-содержащих минералах) [28].
Несмотря на возникающие трудности (флуоресценция, наличие перекрывающихся полос спектра минерала-хозяина и т. д.), рамановский анализ флюидных включений в горных породах возможен. Одним из способов, позволяющих нивелировать появление флуоресценции, является увеличение длины волны возбуждения лазера $(\lambda=630-1060 \mathrm{Hм})[29]$.

В работе [23] получили и интерпретировали спектральную характеристику синтетических флюидных включений с использованием ионного аргонового лазера ( $\lambda=488$ нм), но характеристика спектров осложнялась их высокой флуоресценцией. Поэтому для фиксации спектров пластовой нефти, природных флюидных включений и смеси углеводородов в жидком состоянии в кальцитовой матрице применялся Не-Ne-лазер 632,8 нм низкой мощности (1 и $5 \mathrm{мB}$ ) и длительного время интеграции (от 12 до 24 часов), позволяющий минимизировать возникающую флуоресценцию. Проведенные эксперименты продемонстрировали способность рамановской спектроскопии идентифицировать различные функциональные группы в углеводородных включениях.

В исследованиях [24] были охарактеризованы углеводороды и углеводородные включения с использованием спектроскопии комбинационного рассеяния лазера 514,32 нм при нормальных температуре и давлении. Рамановская спектрограмма углеводородных включений была разделена на пять типов, которые в зависимости от их характеристик содержали во включениях: насыщенные углеводороды; нефть и газ; насыщенные углеводородные битумы; битумы и растворенный в воде метан.

Применение лазера с длиной возбуждения 785 нм с подходящими оптическими параметрами и специальными технологиями подготовки пластин позволили получить спектры комбинационного рассеяния из природных флюидных включений без перекрывающей КР-сигналы фоновой флуоресценции [27]. Экспериментально показано, что длина волны возбуждения 785 нм превышает длину волны поглощения ароматического углеводорода, помогая искоренить их флуоресценцию. Изучения флюидных включений проводились в диагенетических цементах и минеральных агрегатах вторичных трещин из образцов терригенных и карбонатных пород одного из нефтяных месторождений Индии. В результате исследований Jayanthi et al (2017) в образцах установили, помимо пиков КР-спектров оксидов углерода и серы, азота, этилена, циклогексана, бензола и бромбензола, карбонилсульфида, жидкой формы сероводорода, соответствующих углеводородам и углеводородсодержащим компонентам, широкие пики спектров жидкой воды (3100-3500 $\left.\mathrm{cm}^{-1}\right)$, карбоната и сульфата кальция, что является индикатором природы нефти в бассейне.

Целью работы являлось определение с помощью спектроскопии комбинационного рассеяния 
состава газово-жидких включений в доломитизированных карбонатных породах Северо-Останинского нефтяного месторождения, позволяющих получить информацию о составе флюидного раствора и его влиянии на образование вторичных доломитов в известняках, в связи с приуроченностью к ним зон нефтегазонакопления.

В статье приводится качественное описание особенностей полученных спектров комбинационного рассеяния при определении флюидных включений и предлагается их интерпретация.

\section{Геологическое строение}

Северо-Останинское нефтегазоконденсатное месторождение располагается на юго-востоке Западно-Сибирской нефтегазоносной провинции в Парабельском районе Томской области. В тектоническом отношении поверхность палеозойского фундамента разбита на ряд блоков нарушениями двух генераций. Основные нарушения северо-западного простирания сформировались при завершении герцинской складчатости, второстепенные северо-восточной ориентировки проявились в триасе и являются более поздними [30-33] (рис. 1).

В результате дифференцированных движений по разломам на доюрскую поверхность выведены породы разного возраста и состава.

Палеозойские отложения Северо-Останинской площади, входящей в состав Нюрольского структурно-фациального района (СФР), согласно существующему стратиграфическому расчленению, представлены отложениями ордовика, силура, девона, карбона.

Осадконакопление в самом начале девона проходило в теплом эпиконтинентальном море с хорошей циркуляцией воздуха в водной среде и вместе с умеренной вулканической деятельностью эти обстоятельства являлись благоприятными для развития рифостроящих организмов [34].

Подобные условия были типичными и для нижнего девона Нюрольского структурно-фациального района (СФР), где отмечается накопление отложений рифогенного и депрессионного типа. Главными их признаками являются наличие органогенных известняков и доломитов, глинистокремнистых пород, чередующихся с черными и черно-коричневатыми аргиллитами [35].

В начале позднего девона в Евразии произошла трансгрессия, которая вызвала исчезновение географических барьеров и интеграцию фаун. Общий подъем относительного уровня моря привел к накоплению органогенных, рифогенных известняков с подчиненными прослоями аргиллитов. Существовала весьма разнообразная фауна кораллов и других бентосных организмов в шельфовой части (чарымовская серия - герасимовская свита). В бассейновой части (тартасская серия - чузикская свита) формировались темно-серые глинистые, водорослевые известняки, пелоидные из- вестняки, алевролиты с редкими остатками тентакулит, глинисто-кремнистые породы, т. е. формирование пород характеризуется увеличением глинистости и кремнистости в отложениях бассейновых фаций при одновременном существовании рифогенных построек на шельфе [34, 35].

Отложения герасимовской свиты являются хорошими коллекторами, особенно в пределах их выхода на древнюю эрозионно-тектоническую поверхность фундамента [36].

К франскому и фаменскому времени произошло изменение водной среды обитания организмов, в результате почти полностью исчезли кораллы и развились фораминиферы. В шельфовом комплексе создались условия для накопления темносерых массивных водорослево-фораминиферовых известняков с редкими прослоями туфолав базальтового состава (чарымовская серия - лугинецкая свита). В бассейновом комплексе увеличилось поступление кремнистого материала (тартасская серия - чагинская свита) [34].

Литологическая характеристика отложений лугинецкой свиты и наличие в ней признаков нефти и газа свидетельствуют о том, что она является потенциальным резервуаром для скоплений нефти и газа (пл. Северо-Останинская) [36].

Доюрские породы Западной Сибири, которые представляют интерес с точки зрения поиска углеводородов, делятся на три самостоятельных объекта поиска скоплений углеводородов:

1) кровля доюрских отложений и развитая по ним кора выветривания;

2) эффузивно-осадочные отложения пермотриасового комплекса;

3) внутренние горизонты палеозоя с залежами углеводородов, приуроченных к трещиноватокавернозным карбонатным породам с осложненной складчатостью и процессами вторичного изменения.

Продуктивные горизонты в доюрских отложениях изучаемого региона представлены зоной контакта отложений палеозоя и мезозоя (разновозрастный нефтегазоносный горизонт зоны контакта - НГГЗК) и собственно палеозойскими структурами [37]. По существующей индексации нефтеперспективных объектов в НГГЗК выделяют пласты М (кора выветривания) и $\mathrm{M}_{1}$ (кровельная часть палеозойского фундамента), а в отложениях глубинного палеозоя - пласт $\mathrm{M}_{2}$.

Разрез палеозойских отложений Северо-Останинского месторождения, к которому приурочен продуктивный пласт, преимущественно сложен доломитами, известняками органогенными и доломитовыми, глинисто-кремнистыми, глинистыми с редкими прослоями вулканитов. По предлагаемой индексации нефтегазоносный объект относится к пласту $\mathrm{M}_{1}$ и приурочен к зоне доломитизации биогермной постройки. 
a)

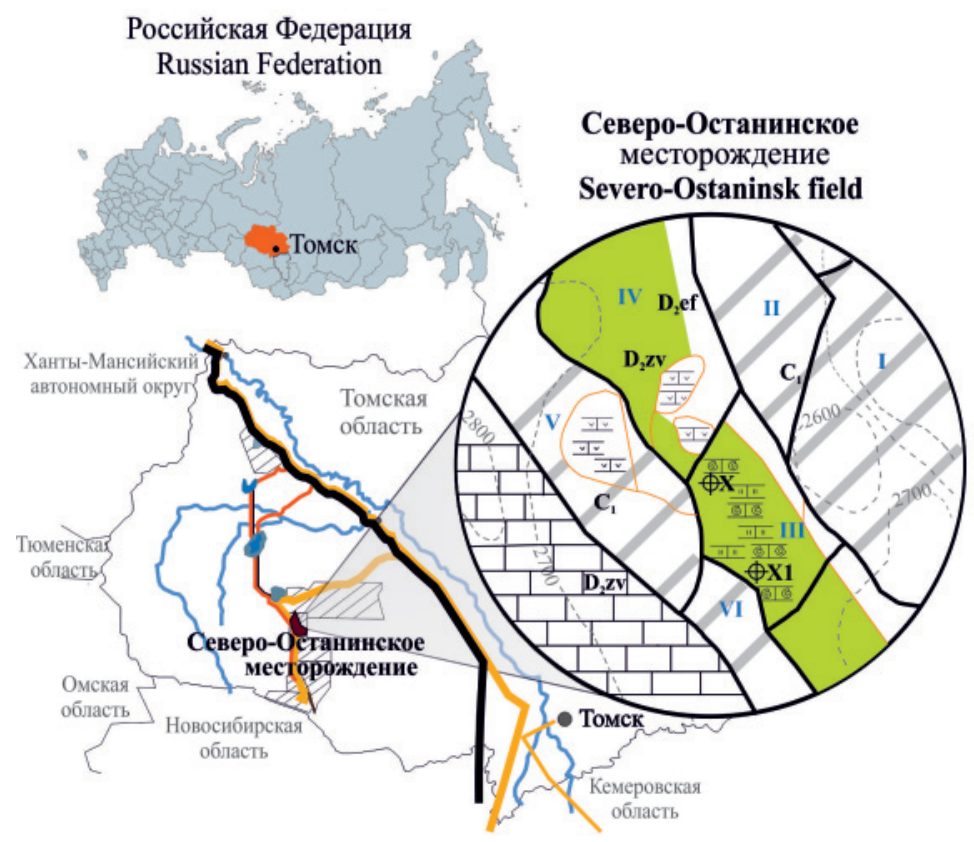

Условные обозначения / Legend

- Газопровод/gas pipeline

- Продуктопровод/ product line

- Нефтепровод/ oil-pipeline

Газоконденсатное месторождение / gas-condensate field

$\square$ Нефтегазоконденсатное месторождение / oil-gas condensate field

Нефтяное месторождение / oil field

> Дизъюнктивные нарушения / disjunctive dislocation

$\varnothing$ Скважина / well

VI Номера блоков / block number б)

Сводная стратиграфическая колонка / Summary stratigraphic column

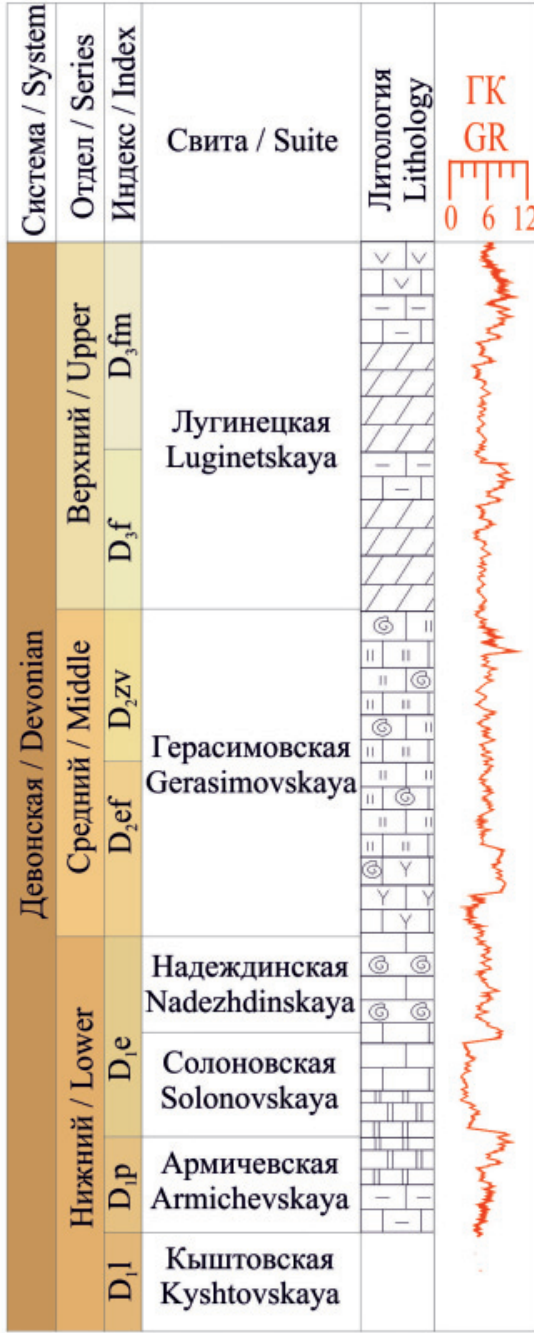

Изогипсы кровли фундамента / structural contour of basement roof

Порода глинисто-кремнистая / argillaceous-siliceous rock

Доломит по органогенным известнякам / dolomite on organogenic limestone

Известняк / limestone

Известняк органогенный organogenic limestone

Үу⿴囗十 Известняк водорослевый limestone marine algae
듬ㄱ Известняк глинистый argilliferous limestone

Известняк доломитизированный dolomitic limestone

Птвестняк окремненный silicified limestone
Аргиллит / argillite

且 Мергель / marl

臣西 Доломит / dolomite

藏 Эффузивы / effusive

Pис. 1. Расположение, схема тектонического строения поверхности палеозойского фундалента (а) и сводная стратиграфическая колонка (б) Северо-Останинского месторождения

Fig. 1. Location, structure-tectonic scheme of the surface of the Paleozoic basement (a) and summary stratigraphic column (ס) of the SeveroOstaninsk oil field

\section{Методы и объекты исследований}

\section{Объекты исследования}

Двадцать шесть шлифов, изготовленных из образцов керна карбонатных пород скважин X и X1 Северо-Останинского месторождения, предвари- тельно изучались на оптическом поляризационном микроскопе Olympus® BX-53-F. По результатам исследований шлифов отобраны образцы пород, в которых фиксировалось развитие доломита. Перед аналитическими процедурами с использова- 
нием рамановской спектроскопии для определения состава флюидных включений в доломите из керна изготавливались двусторонние полированные пластины толщиной 0,3 мм. Основываясь на петрографическом анализе шлифов и пластин, проводилось ультрафиолетовое флуоресцентное микроскопическое их изучение для установления различных включений нефти с использованием ртутной лампы с 350 нм.

\section{Приборы и методы обработки}

Идентификация углеводородных флюидных включений в доломите осуществлялась с помощью дисперсионного конфокального микроскопа комбинационного рассеяния Thermo Fisher Scientific DXR2 в лаборатории Инженерной школы природных ресурсов Томского политехнического университета. Выбор объекта исследования и наблюдение за ним проводились с помощью микроскопа и/или видеокамеры, передающей изображение в управляющую программу OMNIC. Оперативная настройка и калибровка прибора происходила автоматически под контролем программного обеспечения с использованием неоновой лампы, калиброванной лампы белого света и пластинки из полистирола.

Прибор использует диодный лазер с длиной волны возбуждения 785 нм, характеризующийся наилучшим соотношением «уменьшение флуоресценции и спектральное разрешение». Спектральный диапазон оборудования для указанного лазера составляет от 50 до $3360 \mathrm{~cm}^{-1}$ лазерной линии. Частота 50 Гц \pm 1 . Мощность возбуждающего лазера (мощность на пробе) регулируется с шагом 0,1 мВт до максимума 30 мВт и при определении она составляла 15 мВт. Использовались объективы с 50-ти и 100-кратным увеличением и апертура 50 мкм. Диаметр лазерного пятна составлял не более 2 мкм в фокальной плоскости.

Измерение и получение спектров флюидных включений проводилось при картировании на глубину с целью захвата газовой фазы, которая находилась на некотором удалении вглубь от поверхности пластины. При построении спектральной карты распределения компонентов по глубине в исследуемых пластинах задавались 15-30 точек с шагом 1 мкм, время экспозиции задавалось 5 с, число экспозиций 3 на точку. Полученные накопленные спектры в каждой точке измерения обрабатывались с использованием программного обеспечения Omnic ver. 9.3.03. (Thermo Fisher Scientific, Inc.), поставляемого со спектрометрической системой.

При обработке спектров применялась автоматическая коррекция флуоресценции. Спектры копировались в рабочий лист Origin-Pro® 2018, где выполнялось сглаживание (удаление шума из спектра) и вычитание базовой линии. Применялся сглаживающий фильтр Савицкого-Голея (Savitzky-Golay) с использованием 21-точечного квадратичного полиномиального алгоритма, что помога- ет извлекать информацию из экспериментальных данных с большими шумами. Правильный подбор параметров не размывает пики и спады спектра, и при выполнении сглаживания можно выбирать позиции полосы с большей долей вероятности, что соответствующий спектр лучше подходит к исходному анализируемому спектру.

С использованием модуля Peak Fitting OriginPro® 2018 проводилась деконволюция (расщепление КР-спектра), что позволяет идентифицировать скрытые пики в спектре и определенные спектральные параметры для отдельных полос. При деконволюции выбиралось произвольное начальное приближение с использованием минимального числа кривых Лоренца во избежание чрезмерного усложнения задачи. Ориентиром служит визуальное совпадение экспериментальной кривой и линейной аппроксимации кривых Лоренца.

Совпадение подобранных пиков и параметров определяется значением коэффициента детерминации $\mathrm{R}^{2}$, который статистически показывает, насколько хорошо соответствующий спектр коррелирует с исходным спектром. Значения коэффициента, близкие 1 , означают, что соответствие полученной кривой сходится с наблюдаемым спектром. Полученные значения $\mathrm{R}^{2}$, применимо к исследуемым спектрам газово-жидких включений, варьировали в пределах 0,91-0,98.

\section{Результаты}

Петрография карбонатных пород

Северо-Останинского месторождения

Изученные породы скв. X и X1 представлены карбонатными отложениями - известняками и доломитами. Известняки органогенно-обломочные (био-литокластические), пелитоморфные с участками перекристаллизации, часто кальцитизированные и доломитизированные. При интенсивной доломитизации формируются неравномернозернистые разности доломитов замещения по органогенным известнякам. В скв. Х1 преобладают известняки слабо доломитизированные (содержание не превышает 3-7 \% ), в скв. Х содержание доломита увеличивается до 35-45 \% , вплоть до перехода органогенного известняка в доломит.

Известняки имеют трещиноватую и пятнистую текстуру. Фиксируются стилолитовые швы, часто выполненные глинистым веществом, и разнонаправленные прожилки кальцита. Неравномерно распределенные в породе стилолиты, иногда сливающиеся в системы, указывают на процессы уплотнения породы, происходившие в процессе диагенеза (рис. 2, а.1). Кальцитовые трещины встречаются нескольких генераций, более выраженные в керне ранние трещины пересекаются тонкими кальцитовыми трещинами, являющимися более поздними. Пятнистый рисунок пород проявляется за счет неравномерного распространения в них перекристаллизованных участков с остатками слоевищ водорослей (рис. 2, а.2). В этом случае наблюдается проявление чистого, без химических 

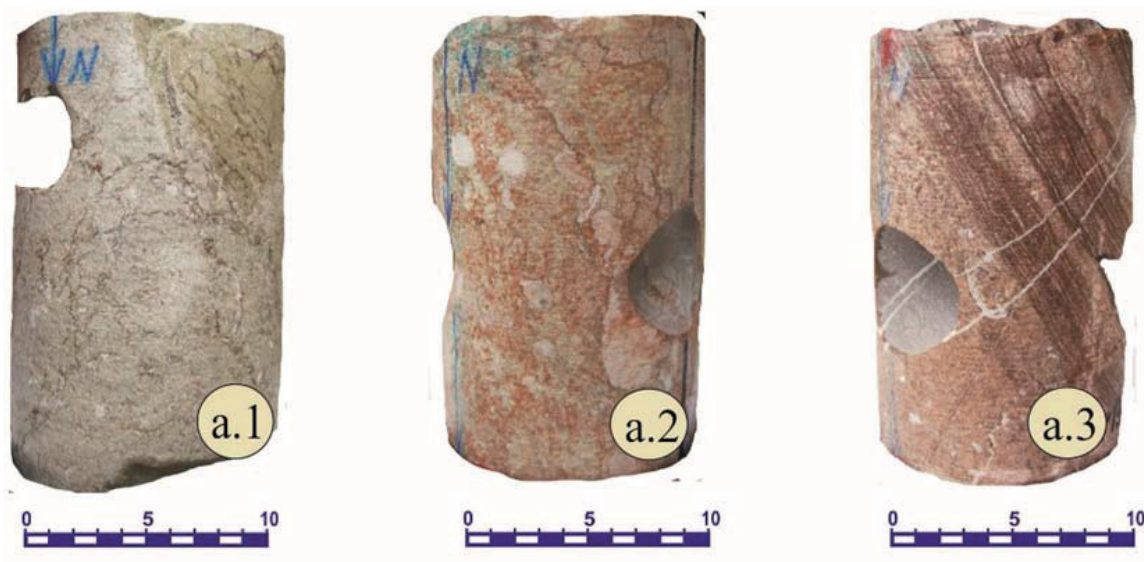

Известняки органогенно-обломочные: / organogenic-bioclastic limestones

a.1 - стилолитовые швы / styllolite seams

a.2 - текстура пятнистая / mottled structure

а.3 - текстура слоистая с прожилками кальцита / stratified structure with calcite vein

Pис. 2. Текстуры известняков Северо-Останинского месторождения

Fig. 2. Limestone structure of the Severo-Ostaninsk field

и механических примесей, кристаллически зернистого белого кальцита.

В отдельных образцах отмечается слоистая текстура, обусловленная выделениями рудного (гематитового), реже битуминозного материала, пропитывающего отдельные прослои известняков в сочетании с послойным же развитием доломитового агрегата (рис. 2, а.3).

Структура известняков, на фоне которой обособляются сгустки и комковатые выделения, пелитоморфная. Окатанные обломки пелитоморфного (пелоидного) известняка могут цементироваться тонко-мелкокристаллическим кальцитом.

Форменные образования представлены овально-округлыми либо концентрически-зональными выделениями, напоминающими оолиты, во внутренней зоне которых отмечается тонкозернистый кальцит и доломит Д1 (рис. 3, а.1). Последний может нарастать на форменные образования в виде тонких кристаллических зерен. Доломитизация проявляется также в межформенном пространстве вблизи оолитовых формирований и в межформенных порах. Мелко-среднезернистые кристаллы доломита Д2 и Д3 различаются по месту локализации в породах. Первые развиваются в трещинном пространстве известняков. Вторые, часто имеющие правильную или частично правильную форму ромбоэдров, выделяются по периферии крупных межформенных пор или крупных, скорее всего, ранних трещин, либо развиваются в основной массе породы (рис. 3, а.2, а.3, а.4). Доломиты Д3, развиваясь в основной матрице карбонатного состава в результате метасоматических процессов, могут сохранять между ромбоэдрами поры и пустоты. В зернах кристаллически зернистого доломита Д2 и Д3 фиксируются флюидные включения с движущимися газовыми пузырями при комнатной температуре.
Макрофауна не имеет хорошей сохранности, отмечаются единичные целые раковинки остракод и фораминифер. Органические остатки представлены фрагментами криноидей, мшанок, водорослей, кораллов и брахиопод, полностью замешенных карбонатным веществом (рис. 3, а.5, а.6).

В отдельных участках изученного разреза скв. $\mathrm{X}$ к зонам доломитизации приурочены области развития гематита, частично с битуминозным веществом, что придает породе коричневато-красный цвет. Гематит пропитывает зерна доломита и слагающую матрицу породы, формирует неправильные сгустковые выделения и пятна (рис. 3 , а.7). Совместное его проявление с битуминозным коричневато-бурым веществом не всегда позволяет их правильно идентифицировать. Наличие преобладающего гематита, по сравнению с битуминозным компонентом, подтверждает полученный спектр комбинационного рассеяния минерала (рис. 3, а.8), рентгенофлуоресцентный анализ и люминесцентно-битуминологические исследования шлифов пород.

В известняках в участках перекристаллизации по периферийной части выделяются крустификационные проявления мелких кристаллов кальцита, часто с подчеркнутой гематитовым агрегатом внутренней зоной, центральная часть выполняется крупнокристаллическим кальцитом.

Битуминозность иногда отмечается в виде примазок, небольших сгустков, может наблюдаться в трещинном пространстве вместе с карбонатным агрегатом.

Пустоты (каверны, трещины или межформенные поры) в породах заполнены карбонатными минералами: доломитом и/или кальцитом, реже выполнены серо-зеленоватым глинистым веществом. 

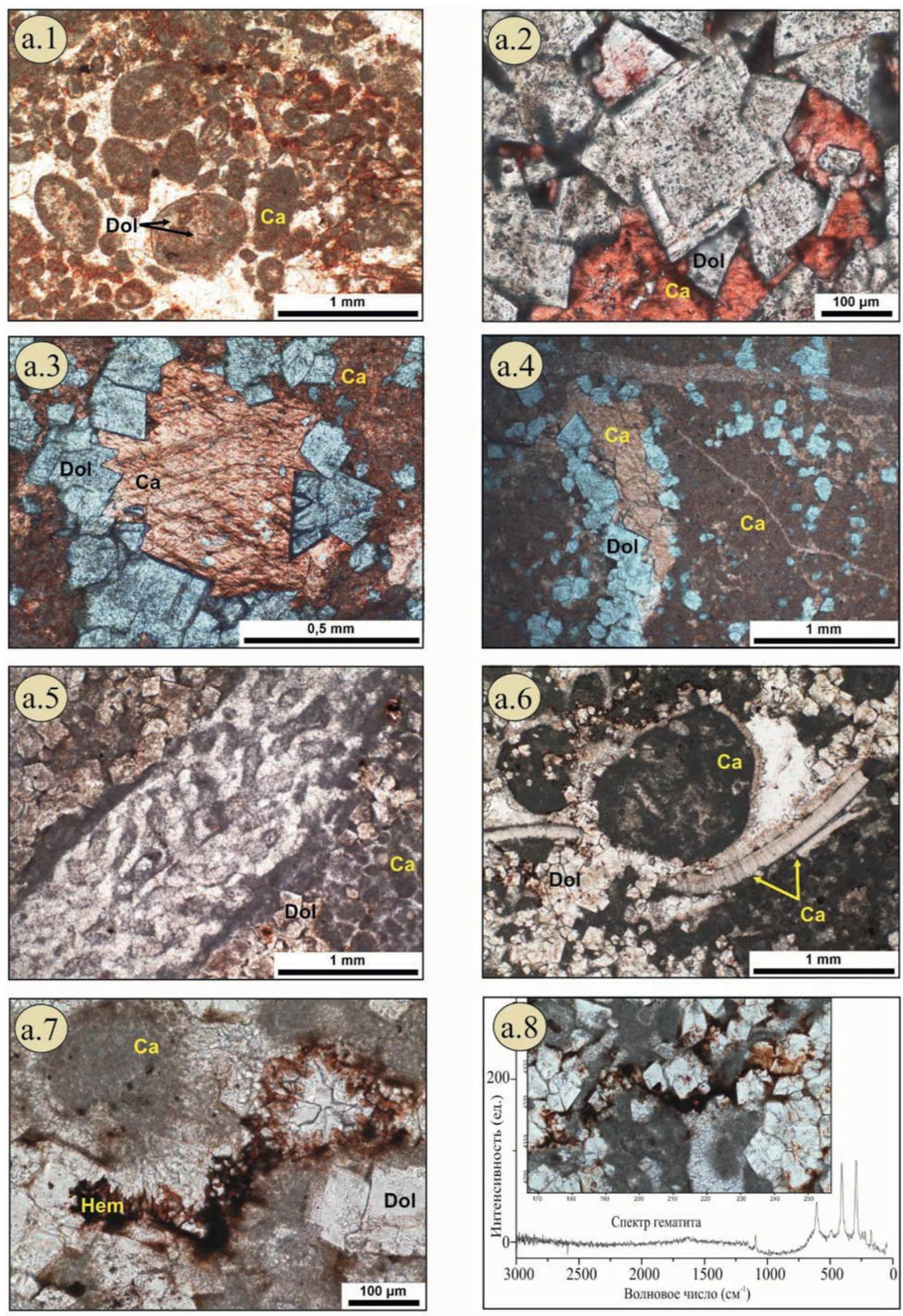

Ca - кальцит / calcite; Dol - доломит / dolomite; Hem - гематит / hematite

Рис. 3. Фотографии шлифов известняков Северо-Останинского месторождения (а.1-а.7) и спектр гематита (а.8): а.1 - форменные образования известняков; а.2-а.4 - ромбоэдры доломита в карбонатной матрище пород; а.5, а.6 - органические остатки, замещенные кальцитол; а.7 - выделения гематита; а.8 - КР-спектр гематита

Fig. 3. Photographs of limestone thin sections of the Severo-Ostaninsk deposit (a.1-a.7) and the spectrum of hematite (a.8): a.1 - uniform limestone formations; a.2-a.4 - rhombohedra of dolomite in a carbonate matrix; a.5, a.6 - organic remains, substituted with calcite; a.7-hematite precipitations; a.8 - Raman spectrum of hematite 


\section{Типы флюидных включений}

Микроскопические наблюдения флюидных включений в восьми пластинах показали, что палеофлюиды, захваченные минералом-хозяином, могут выступать в качестве первичных или вторичных флюидных обособлений в соответствии с критериями, указанными [2, 38].

Для точной идентификации первичных флюидных включений существует только один действительный критерий, а именно идентификация петрографической связи с ростом кристалла. Вторичные и псевдо-вторичные включения первоначально могут наследовать форму перекристаллизованного минерала хозяина.

Первичные флюидные включения обнаружены в доломитах Д2 и Д3, согласно выделенным ранее авторами фазам доломитизации на месторождении (рис. 4). Для доломитов Д2 первичные флюидные включения были ограничены зонами роста и ориентированы параллельно граням кристалла. Флюидные включения вытянутой и удлиненной формы размером 3-5 $\mu$ м встречаются и в центральной части, и по периферии кристаллов доломита. В замещающих доломитах ДЗ внутренней зоны роста не наблюдается, однако изолированные флюидные включения в кристалле интерпретируются как первичные для доломита (но вторичные относительно самой породы - известняка), поскольку обнаруживают правильную ромбическую форму флюидного включения с заключенной в него газовой фазой, paспределение идет вдоль направления роста кристаллов. Измеряемые вдоль самой длинной стороны включения достигают размеров до $10 \mu \mathrm{M}$.

Петрографические наблюдения позволили установить многочисленные мелкие первичные (или первично-вторичные) флюидные включения, распределенные вдоль зон роста, в кальцитовом материале заполнения трещин и поровых про- странств. Как и с доломитами, данные включения могут считаться первичными для кальцита, но являться вторичными по отношению к протолиту, изменяемому в результате различных процессов диагенеза и метасоматоза.

Все изучаемые флюидные включения имеют две фазы - жидкую и газовую. Последняя составляет около 10-15 \% от общего объема включений.

\section{Характеристика КР-спектров флюидных включений}

При изучении высококонцентированных фаз во флюидных включениях (капельки чистой воды, пузырьки газа, находящиеся под высоким давлением, дочерние минералы) в большинстве случаев интерференция минерала-хозяина не оказывает существенных помех. В то время как определение слабоконцентрированных компонентов (газовые пузырьки, находящиеся при атмосферном давлении, присутствие в малых концентрациях веществ) в растворах проводится с большими трудностями или даже вообще невозможно [2].

Установление характерных значений пиков спектра, таких как положение и площадь пика, является одной из основных целей анализа спектров комбинационного рассеяния. Типичный КРспектр, полученный при исследовании флюидных включений, показал наличие спектров «неизвестного вещества» и минерала-хозяина - доломита (карбоната кальция и магния). Поскольку КР-спектры в жидких включениях показывают широкие перекрывающиеся полосы из-за минеральной матрицы, то наилучшим подходом $\kappa$ их изучению является выбор фонового спектра участков самой минеральной матрицы, свободных от включений (базовой линии минерала-хозяина), затем в пределах флюидного включения жидкой фазовой составляющей (без пузырька) и внутри газо-
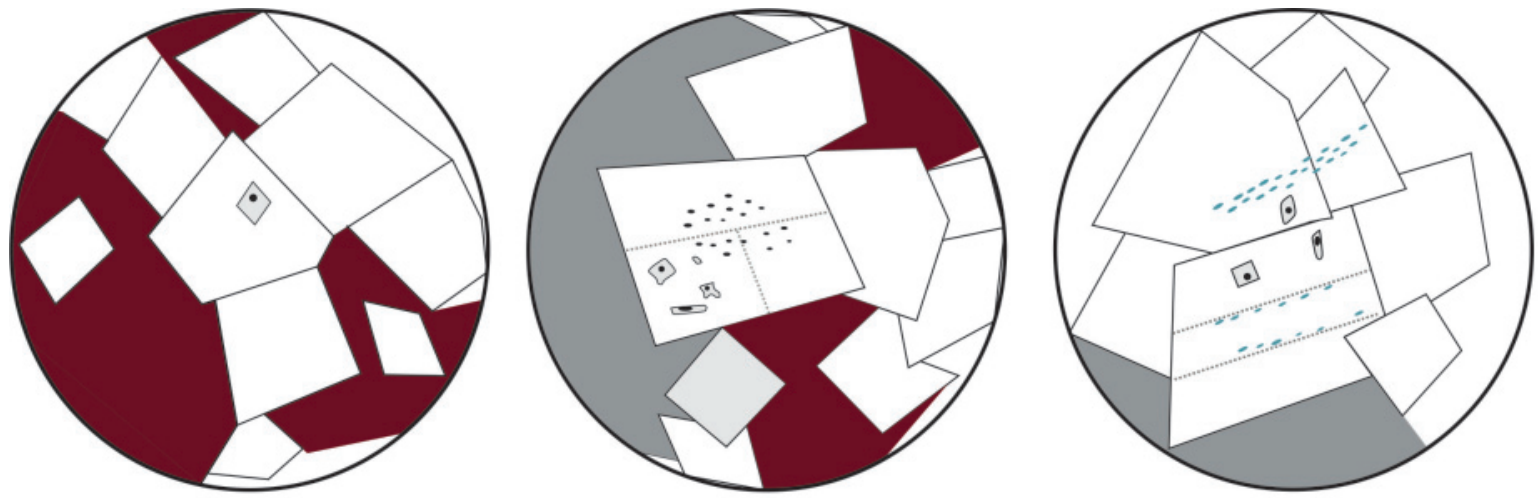

Условные обозначения

пематит/ hemati

(2] доломит/ dolomite

мелкие первичные флюидные включения/ small fluid inclusions

кальцит/ calcite первичные флюидные включения Г-газ; Ж-жидкость primary fluid inclusion G-gas; F-fluid

вторичные флюидные включения/ secondary fluid inclusions

Pис. 4. Зарисовка с пластины двухфазных первичных флюидных включений с преобладанием жидкости, захваченных в зоне роста ромбоэдрических кристаллов доломита ДЗ

Fig. 4. Sketch of two-phase, liquid-dominated primary fluid inclusions trapped in the dolomite D3 growth zone 
вой фазы (пузырька) (рис. 5, a). В этом случае можно установить, какие пики соответствуют матрице и вычесть их из получаемых спектров жидких и газовых фаз флюидных включений.

Например, карбонатные минералы (кальцит и доломит) имеют три различных вида основных пиков в спектре. Однако существенные различия оче- видны в позициях их соответствующих спектров. Для кальцита характерны спектры с пиками $1085\left(v_{1}\right), 1450\left(v_{3}\right)$ и $712 \mathrm{~cm}^{-1}\left(v_{4}\right)$, сетевые виды составляют 156 и $284 \mathrm{~cm}^{-1}$. У доломита имеются основные пики $1097\left(v_{1}\right), 1443\left(v_{3}\right)$ и $725 \mathrm{~cm}^{-1}\left(v_{4}\right)$, сетевые виды находятся в 299 и $176 \mathrm{~cm}^{-1}$, как показано на рис. 5, б.
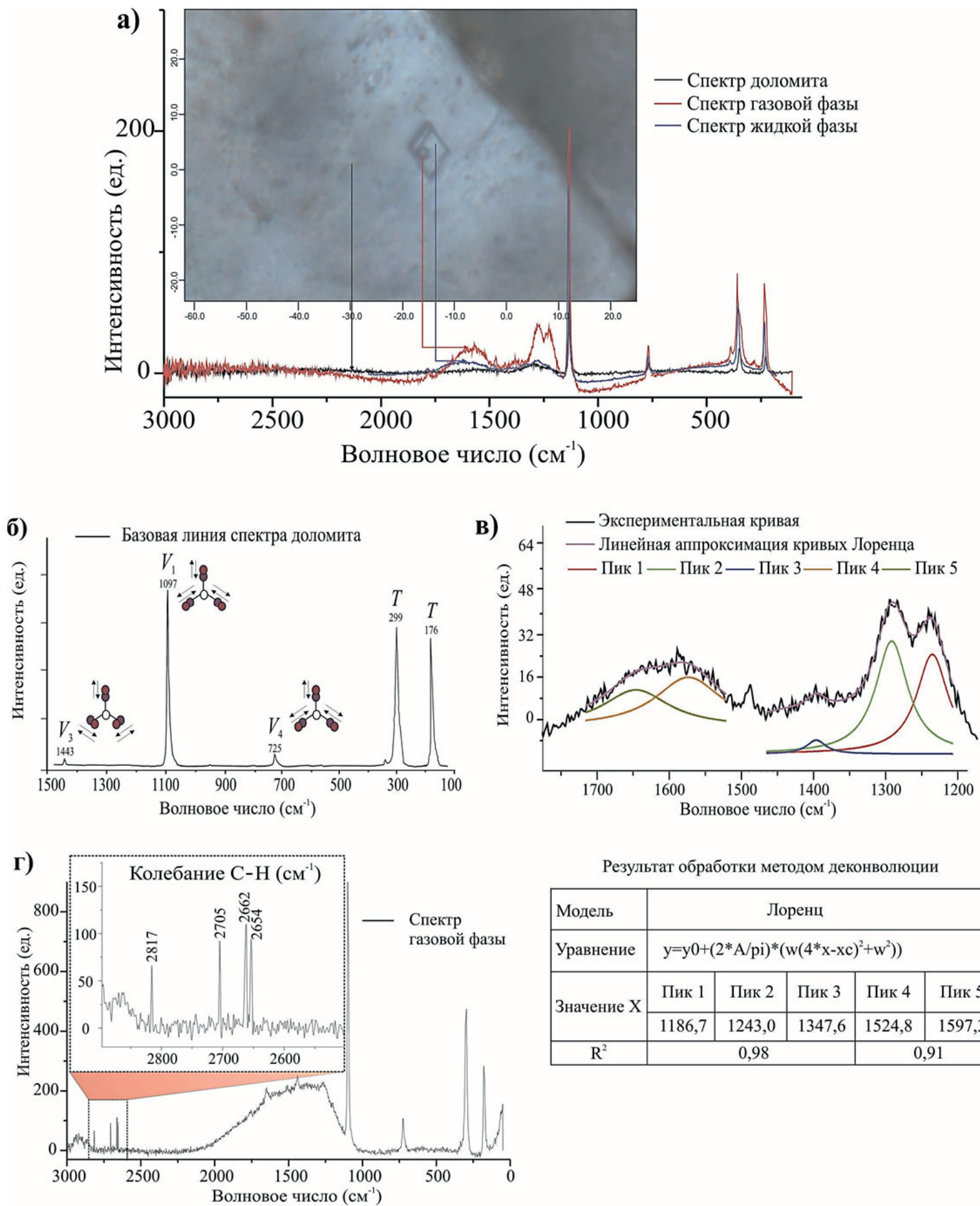

Результат обработки методом деконволюции

\begin{tabular}{|c|c|c|c|c|c|}
\hline Модель & \multicolumn{5}{|c|}{ Лоренц } \\
\hline Уравнение & \multicolumn{5}{|c|}{$\left.\mathrm{y}=\mathrm{y} 0+(2 * \mathrm{~A} / \mathrm{pi}) *\left(\mathrm{w}(4 * \mathrm{x}-\mathrm{xc})^{2}+\mathrm{w}^{2}\right)\right)$} \\
\hline \multirow{2}{*}{ Значение X } & Пик 1 & Пик 2 & Пик 3 & Пик 4 & Пик 5 \\
\hline & 1186,7 & 1243,0 & 1347,6 & 1524,8 & 1597,3 \\
\hline $\mathrm{R}^{2}$ & \multicolumn{3}{|c|}{0,98} & \multicolumn{2}{|c|}{0,91} \\
\hline
\end{tabular}

Pис. 5. Спектры колбинационного рассеяния: а) газовой и жидкой фаз, доломитовой матрицы породы; б) базовый КР-спектр доломита (по [28]); в) пример расщепления (деконволюция) спектров; г) пример спектра второго порядка (колебание С-Н)

Fig. 5. Raman spectrum: a) gas and liquid phases and dolomite matrix; б) base Raman spectrum of dolomite (according to [28]); в) example of splitting (deconvolution) of spectra; 2 ) example of a second-order spectrum ( $\mathrm{C}-\mathrm{H}$ vibration) 
Идентификация сложных спектров, в которых четко проявляется спектр минеральной основной матрицы и отмечается наложение более слабых колебаний других компонентов, как правило, проблематична, но может осуществляться по полосам поглощения. В этом случае «строгих правил для проведения расшифровки спектров не существует» [39], но исследователи различают в спектрах две основные области: область функциональных групп (4000-1500 $\left.\mathrm{cm}^{-1}\right)$ и область «отпечатков пальцев» $\left(1500-625 \mathrm{~cm}^{-1}\right)$.

В настоящей работе авторы предлагают один из возможных примеров определения КР-спектра неизвестного по составу компонента с полосами в области 3360-1150 $\mathrm{cm}^{-1}$ (рис. 5, в, г).

Сравнение экспериментально полученных спектров комбинационного рассеяния со спектрами в опубликованных научных работах показало, что спектральный КР-сигнал, регистрируемый в области первого порядка между 1000 и $2000 \mathrm{~cm}^{-1}$ и второго порядка между 2000 и $3500 \mathrm{~cm}^{-1}$, соответствует углеродистому материалу [40, 41$]$.

Для анализа КР-спектров углеродистого вещества выделяют «упорядоченный» или «графитовый» G-пик, характерный для хорошо кристаллизованного углеродистого материала; «неупорядоченный» или D-пик - для аморфного углеродистого компонента, в котором может фиксироваться также и S-пик. Отметим, что параметры волнового числа всех этих пиков варьируют в зависимости от длины используемого лазера. Так, по данным [42], при применении лазера 514 нм в области 1500 и $1630 \mathrm{~cm}^{-1}$ диапазон частот $\mathrm{G}$ колебаний, соответствующий ароматическим и олефиновым молекулам, будет типичен большому кругу природных органических веществ (OB), в том числе и битумам. На частоте около $1355 \mathrm{~cm}^{-1}$ обычно фиксируется максимум пика D, при этом спектральные линии второго порядка, в большинстве случаев, очень широкие для разупорядоченных органических веществ, проявляются как $\mathrm{S} 2$ линия в области $\approx 2710 \mathrm{~cm}^{-1}$.

Однако полосы сильно неупорядоченных углеродистых материалов (т. е. аморфного углерода) слишком широки и не имеют определенного значения.

Для получения рамановского спектра газовой фазы во флюидном включении и исключения из него спектральных линий доломитовой матрицы и жидкого компонента проводились измерения отдельно в доломите, флюиде и находящемся в нем пузырьке (рис. 5, a). Анализ КР-спектров газовожидких включений установил присутствие полос, характерных для углеродистого материала.

При определении рамановских спектров мелких по размеру газовых включений необходимо учитывать тот факт, что размер пузырька может быть сопоставим с размером пятна лазера или незначительно его превосходить. В этом случае возможно получение спектральных линий углеродистого материала с наложением линий доломита, попадающего в фокальный объем лазерного луча.
Поскольку измеренная интенсивность рамановских видов прямо пропорциональна концентрации, то отношение сигнал-шум рассеяния углеродистого материала ниже, а доломита, занимающего относительно больший объем в исследуемых образцах, выше, что способствует большему рамановскому рассеянию в спектре.

Спектры комбинационного рассеяния, полученные из газовых фаз флюидных первичных включений в кристаллах доломита в разных пластинах, показаны на рис. 6.

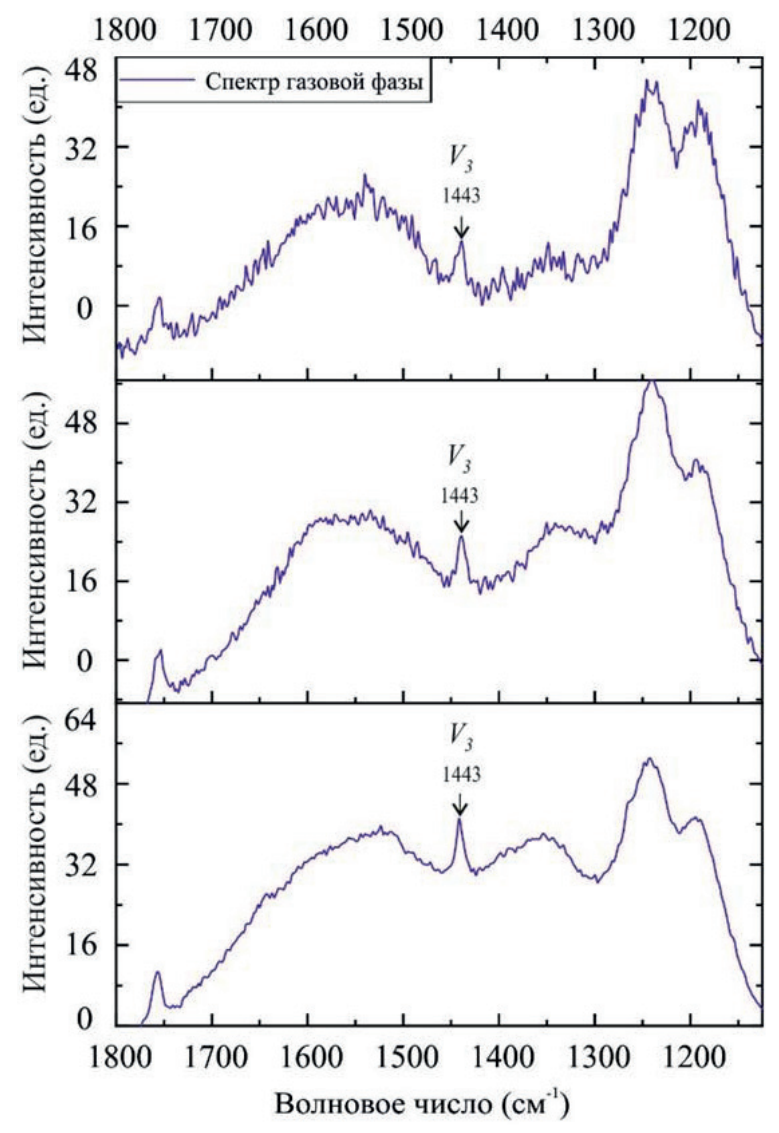

Puc.6. Спектры комбинационного рассеяния газовой фазы из ГЖВ в доломитах. $V_{3}-$ пик хозяина-минерала (доломита)

Fig. 6. Raman spectra of the gas phase from fluid inclusions in dolomites. $V_{3}$ is one of the peaks of the host mineral (dolomite)

Однако, как и в случае с различными формами аморфного углерода, не существует уникального спектра углеродистого материала [43]. Последний представляет собой сложный материал с точки зрения химии $(\mathrm{C}, \mathrm{H}, \mathrm{O}, \mathrm{N})$, содержащий, помимо возможной твердой фазы, легкие углеводородные остатки или летучие компоненты. Углерод обладает уникальной универсальностью своей химической связи между элементами. Существование углеродных двукратных $\left(\mathrm{sp}^{1}\right)$, трехкратных $\left(\mathrm{sp}^{2}\right)$ и четырехкратных $\left(\mathrm{sp}^{3}\right)$ гибридизованных типов связывания отвечает за огромное разнообразие более десяти миллионов органических соединений [44]. Возможно, поэтому полученные спектры очень похожи на спектры аморфного элементарного углерода. 


\section{Обсуждение результатов}

Изучение петрографических особенностей карбонатных отложений скв. Х и X1 Северо-Останинского месторождения позволило установить основные разновидности пород, слагающих разрезы скважин: известняки органогенно-обломочные, известняки доломитизированные и доломиты. Вторичная доломитизация в скважинах проявлена неоднозначно, и содержание доломита в карбонатных породах скв. Х (35-45\%) в несколько раз превышает его количество в скв. X1 (3-7 \%). Первопричиной отмеченных несовпадений могут являться различия в процессе доломитизации карбонатного органогенного рифового массива, связанные с мозаичностью и зональностью его строения, в том числе, в связи с проявлениями тектонических нарушений, разбивающих поверхность фундамента месторождения на ряд блоков.

Форма и локализация доломита в карбонатных породах, установленная в результате изучения шлифов, позволяет выделять три основные фазы доломитизации:

1. Доломит 1 (Д1) - пелитоморфный и микро-тонкозернистый агрегат, слагающий основную матрицу породы.

2. Доломит 2 (Д2) - кристаллический доломит, развивающийся в трещинах пород.

3. Доломит 3 (Д3) - относительно правильные ромбоэдрические кристаллы, возникающие в основной матрице карбонатного состава в результате метасоматических процессов, между которыми могут сохраниться пустоты.

Флюидные включения, в которых проводилось определение КР-спектров газовой составляющей, наблюдались в кристаллически зернистых агрегатах доломитов $2^{\text {ой }}\left(\right.$ Д2) и $3^{\text {ей }}$ (Д3) фазы.

Типичные спектры комбинационного рассеяния газовой фазы флюидных включений для различных образцов показывают очень слабую структурную организацию углеродистого материала и имеют две очень широкие полосы вокруг 1150-1380 и 1470-1670 $\mathrm{cm}^{-1}$ (рис. 6). Поскольку точное положение полос было неясным, применялся процесс расщепления (деконволюции) спектров для наблюдения скрытых характеристик (рис. 5, в). Значения разложения спектра комбинационного рассеяния следует рассматривать как приблизительные, и в данном исследовании именно они будут применяться для определения положений пиков. Полученные после деконволюции спектры являются сложными с несколькими полосами: 1187, 1243, 1348,1525 и $1597 \mathrm{~cm}^{-1}$.

Положение полосы для углеродистых материалов зависит от длины волнового возбуждающего лазера $[43,45,46]$. Пики между 1150 и $1265 \mathrm{~cm}^{-1}$ появляются в органическом материале, содержащем кероген, или в сильно разупорядоченном углеродсодержащем материале, но отсутствуют в чисто графитовых или сильно обугленных материалах. Появление таких пиков обычно объясняется растягивающими колебаниями $\mathrm{C}-\mathrm{C}$ или $\mathrm{C}=\mathrm{C}$ неупорядоченной графитовой сети $[47,48]$. В исследованиях [43] использовали лазер длиной 1064 нм и определили пик при $1185 \mathrm{~cm}^{-1}$ как пик $\mathrm{S}$, который представляет $\mathrm{sp}^{2}-\mathrm{sp}^{3}$ углеродсодержащие структуры в буром угле. Происхождение пика $\mathrm{S}$ объясняется колебаниями $\mathrm{C}_{\text {aromatic }}-\mathrm{C}_{\text {alky }}$; ароматических эфиров, C-C и $\mathrm{C}-\mathrm{H}$ в ароматических кольцах. Полученные нами при длине лазера 785 нм пики 1187 и 1243 см$^{-1}$ при сопоставлении с пиками спектров других исследователей [45] показывают дисперсию $\pm 2-4 \mathrm{~cm}^{-1}$ и при последующей корректировке положения пиков становятся близки к аналогичным, выделенным [43], и характеризуют кероген (незрелое органическое вещество) $[43,47]$.

Положение наблюдаемых пиков в 1525 и $1597 \mathrm{~cm}^{-1}$, соответствующих вибрационной моде кристаллизованного графита, не могут быть определены как G-полоса, поскольку режим вибрации этой полосы объясняется той же вибрацией неполных графитовых структур [49].

Существует еще одна дополнительная полоса при $1757 \pm 3 \mathrm{~cm}^{-1}$, которая в основном соответствует по структуре кетонам $\mathrm{C}=0$ с режимом растяжения в интервале 1765-1745 $\mathrm{cm}^{-1}$, согласно данным, приведенным KnowItAll@.

В спектрах второго порядка (по [41], это область между 2000 и $3500 \mathrm{~cm}^{-1}$ ) слабо преобразованного углеродистого вещества видны пики при 2654, 2662, 2704 и $2817 \mathrm{~cm}^{-1}$, которые относятся к колебаниям связей $\mathrm{C}-\mathrm{H}$ и $\mathrm{S}-\mathrm{H}$ (рис. 5, , ).

Указанные пики полос в области второго порядка наблюдались не во всех спектрах газовых фаз, что возможно из-за проявления флуоресценции в этом диапазоне спектра.

\section{Заключение}

Показана возможность использования рамановской спектроскопии для изучения флюидных включений в осадочных породах. Рассмотрены процедуры проведения и расшифровки КР-спектров, проанализированы результаты полученных спектров комбинационного рассеяния газово-жидких включений в карбонатных нефтеносных отложениях девона Нюрольской впадины Западной Сибири.

Изучение карбонатных пород, слагающих разрез скв. Х и X1 Северо-Останинского месторождения, позволило выделить несколько фаз образования доломита, отличающихся по размерам и формам проявления в породах. Установлены тонкомикрозернистая основная масса доломита Д1, слагающая совместно с пелитоморфным кальцитом форменные образования пород; кристаллически зернистый агрегат доломита Д2, выполняющий трещины в известняках; частично правильные ромбоэдры вторичного доломита Д3, развивающиеся в участках перекристаллизации исходных пород.

Флюидные включения с четко фиксируемым газовым компонентом наблюдались в кристалли- 
чески зернистых доломитах Д2 и Д3. Проведённые исследования установили присутствие углеводородсодержащих веществ во флюидных включениях вторичных доломитов Северо-Останинского нефтяного месторождения. Наличие этих включений демонстрирует, что образования доломита происходило из флюидов, содержащих углеводородные компоненты. Это наблюдение может дать преимущество для определения времени генерации и миграции нефти в контексте диагенетической и тектонической истории территории.

Результаты, полученные с помощью спектрометрии комбинационного рассеяния газовой составляющей из включений минералообразующих флюидов, показывают, что пики при 1187 и $1243 \mathrm{~cm}^{-1}$ типичны для керогена (незрелого органического вещества). В целом в спектрах газовой фазы определены колебания $\mathrm{C}_{\text {aromatic }}-\mathrm{C}_{\text {alkyl }} ; \mathrm{C}-\mathrm{C}$ в ароматических кольцах, соединения типа $\mathrm{C}=\mathrm{C}$ и типа $\mathrm{C}=\mathrm{O}$.

\section{СПИСОК ЛИТЕРАТУРЫ}

1. Плечов П.Ю. Методы изучения флюидных и расплавных включений. - М.: КДУ, 2014. - 267 с.

2. Рёддер Э. Флюидные включения в минералах. В 2-х т. Т. 1: Природа включений и методы их исследования / Пер. с англ. М.: Мир, 1987. - Т. 1. - 560 с.

3. Рёддер Э. Флюидные включения в минералах. В 2-х т. Т. 2: Использование включений при изучении генезиса пород и руд / Пер. с англ. - М.: Мир, 1987. - Т. 2. - 632 с.

4. The use of integrated fluid inclusion studies in constraining oil charge history and reservoir compartmentation: examples from the Jeanne d'Arc Basin, offshore Newfoundland / J. Parnell, D. Middleton, C. Honghan, D. Hall // Marine and Petroleum Geology. - 2001. V. 18. - № 5. - P. 535-549. DOI: 10.1016/s0264-8172(01)00018-6.

5. Assessing the maturity of oil trapped in fluid inclusions using molecular geochemistry data and visually-determined fluorescence colours / S.C. George, T.E. Ruble, A. Dutkiewicz, P.J. Eadington // Applied Geochemistry. - 2001. - V. 16. - № 4. P. 451-473. D0I: 10.1016/s0883-2927(00)00051-2.

6. Graney J.R., Kesler S.E. Factors affecting gas analysis of inclusion fluid by quadrupole mass spectrometry // Geochimica et Cosmochimica Acta. - 1995. - V. 59. - № 19. - P. 3977-3986. DOI: 10.1016/0016-7037(95)00238-u.

7. Quantitative trace element analysis of single fluid inclusions by proton-induced X-ray emission (PIXE): application to fluid inclusions in hydrothermal quartz / M. Kurosawa, S. Shimano, S. Ishii, K. Shima, S. Kunihiro, T. Kato // Geochimica et Cosmochimica Acta. - 2003. - V. 67. - № 22. - P. 4337-4352. DOI $10.1016 / \mathrm{S} 0016-7037(03) 00378-8$.

8. Microanalysis of fluid inclusions in crustal hydrothermal systems using laser ablation methods / T. Wagner, T. Fusswinkel, M. Wälle, C. Heinrich // Elements. - 2016. - V. 12. - № 5. P. 323-328. D0I: 10.2113/gselements.12.5.323.

9. Synchrotron XRF and XANES investigation of uranium speciation and element distribution in fluid inclusions from unconformity-related uranium deposits / A. Richard, J. Cauzid, M. Cathelineau, M.C. Boiron, J. Mercadier, M. Cuney // Geofluids. 2012. - V. 13. - № 2. - P. 101-111. DOI: 10.1111/gfl.12009.

10. Williams A.E. Mass spectrometric analysis of volatiles in fluid inclusions: aliquot calibration valve to simulate inclusion rupture // Chemical Geology. - 1996. - V. 131. - № 1-4. - P. 155-165. D0I: $10.1016 / 0009-2541(96) 00064-2$
В случае с жидкими включениями говорить об абсолютном обнаружении компонентов сложно, поскольку обнаружение небольших количеств данного вещества зависит не только от количества присутствующих атомов, но и от других присутствующих веществ. Отсутствие стандартных образцов с естественными включениями известного состава для сравнения результатов разных лабораторий затрудняет определение.

Для получения большей информации о составе не только газовых, но и флюидных фаз включений во вторичных доломитах, а также о температурном режиме их образования необходимо провести микротермометрический анализ включений, что позволит максимально использовать геологическую информацию для решения вопроса генезиса вторичных (метасоматических) процессов доломитизации и проследить ее возможную связь с нефтенакоплением в палеозойских породах Северо-Останинского месторождения.

11. Pironon J., Barres 0. FT-IR Microanalysis of hydrocarbon fluid Inclusions // Geochemistry of the Earth's surface and of mineral formation $2^{\text {nd }}$ International Symposium. - France, 1990. P. 224-226. DOI: org/10.1016/0009-2541(90)90220-2.

12. FT-IR measurements of petroleum fluid inclusions: methane, nalkanes and carbon dioxide quantitative analysis / J. Pironon, R. Thiery, M. Ayt Ougougdal, S. Teinturier, G. Beaudoin, F. Walgenwitz // Geofluids. - 2001. - V. 1. - № 1. - P. 2-10. DOI: $10.1046 / \mathrm{j} .1468-8123.2001 .11002 . x$.

13. Kihle J. Adaptation of fluorescence excitation-emission microspectroscopy for characterization of single hydrocarbon fluid inclusions // Organic Geochemistry. - 1995 . - V. 23. - № 11-12. P. 1029-1042. DOI: 10.1016/0146-6380(95)00091-7.

14. Wopenka B., Pasteris J. D., Freeman J. J. Analysis of individual fluid inclusions by Fourier transform infrared and Raman microspectroscopy / Geochimica et Cosmochimica Acta. - 1990. - V. 54. - № 3. P. 519-533. DOI: 10.1016/0016-7037(90)90349-p.

15. Burke E.A. Raman microspectrometry of fluid inclusions // Lithos. - 2001. - V. 55. - № 1-4. - P. 139-158. DOI: $10.1016 / \mathrm{s} 0024-4937(00) 00043-8$.

16. Jehlička J., Edwards H.G. Raman spectroscopy as a tool for the non-destructive identification of organic minerals in the geological record // Organic Geochemistry. - 2008. - V. 39. - № 4. P. 371-386. DOI: 10.1016/j.orggeochem.2008.01.005.

17. Raman microspectroscopy, bitumen reflectance and illite crystallinity scale: comparison of different geothermometry methods on fossiliferous Proterozoic sedimentary basins (DR Congo, Mauritania and Australia) / B. Baludikay, C. François, M. Sforna, J. Beghin, Y. Cornet, J. Storme, N. Fagel, F. Fontaine, R. Littke, D. Baudet, D. Delvaux, E. Javaux // International Journal of Coal Geology. - 2018. - V. 191. - P. 80-94. DOI: 10.1016/j.coal.2018.03.007

18. Fast and accurate shale maturity determination by Raman spectroscopy measurement with minimal sample preparation / B. Sauerer, P. Craddock, M. Aljohani, K. Alsamadony, W. Abdallah // International Journal of Coal Geology. - 2017. - V. 173. P. 150-157. DOI: 10.1016/j.coal.2017.02.008

19. Khatibi S., Ostadhassan M., Aghajanpour A. Raman spectroscopy: an analytical tool for evaluating organic matter // Journal of Oil, Gas and Petrochemical Sciences. - 2018. - V. 1. - № 1. P. 28-33. DOI: $10.30881 /$ jogps.00007

20. Tobola T. Raman spectroscopy of organic, solid and fluid inclusions in the Oldest Halite of LGOM area (SW Poland) // Spectrochimica 
Acta. Part A: Molecular and Biomolecular Spectroscopy. - 2018. V. 189. - P. 381-392. DOI: 10.1016/j.saa.2017.08.024

21. Assessment of UV-Raman for analysis of petroleum inclusions / J. Bourdet, R.C. Burruss, R.J. Bodnar, P.J. Eadington // European Current Research on Fluid Inclusions (ECROFI-XXI). - Austria: Montanuniversität Leoben, 2011. - P. 50-51.

22. Burke E.A., Lustenhouwer W.J. The application of a multichannel laser Raman microprobe (Microdil-28®) to the analysis of fluid inclusions / Chemical Geology. - 1987. - V. 61. - № 1-4. P. 11-17. DOI: $10.1016 / 0009-2541(87) 90021-0$.

23. Raman spectroscopy of crude oils and hydrocarbon fluid inclusions: a feasibility study / D. Orange, E. Knitile, D. Farber, Q. Williams // Mineral Spectroscopy. - 1996. - V. 5. - № 5. P. 65-81. URL: https://www.tib.eu/en/search/id/BLCP $\%$ 3ACN024271905/Raman-spectroscopy-of-crude-oils-and-hydrocarbon/ (дата обращения 18.10.2018).

24. Raman characteristics of hydrocarbon and hydrocarbon inclusions / N. Zhang, Z. Tian, Y. Leng, H. Wang, F. Song, J. Meng // Science in China Series D: Earth Sciences. - 2007. - V. 50. № 8. - P. 1171-1178. DOI: 10.1007/s11430-007-0078-9.

25. Characterization of hydrocarbon-bearing fluid inclusion in sandstones of Jaisalmer basin, Rajasthan: A preliminary approach / D. Verma, G.N. Jadhav, T.K. Biswal, S K. Jena, N. Sharma // Journal of the Geological Society of India. - 2012. - V. 80. № 4. - P. 505-514. DOI: 10.1007/s12594-012-0170-4.

26. Nandakumar V., Jayanthi J. L. Hydrocarbon fluid inclusions, API gravity of oil, signature fluorescence emissions and emission ratios: an example from Mumbai offshore, India // Energy \& Fuels. - 2016. - V. 30. - № 5. - P. 3776-3782. DOI: 10.1021/acs. energyfuels.5b02952.

27. Jayanthi J.L., Nandakumar V., Anoop S.S. Feasibility of a $785 \mathrm{~nm}$ diode laser in Raman spectroscopy for characterizing hydrocarbon-bearing fluid inclusions in Mumbai Offshore Basin, India // Petroleum Geoscience. - 2017. - V. 23. - № 3. P. 369-375. DOI: $10.1144 /$ petgeo2016-071.

28. Frezzotti M.L., Tecce F., Casagli A. Raman spectroscopy for fluid inclusion analysis // Journal of Geochemical Exploration. 2012. - V. 112. - P. 1-20. DOI: 10.1016/j.gexplo.2011.09.009.

29. Carey P.R. Raman Spectroscopy, the sleeping giant in structural biology, awakes // Journal of Biological Chemistry. - 1999. - V. 274. № 38. - P. 26625-26628. DOI: 10.1074/jbc.274.38.26625.

30. Опыт комплексного сейсмофациального анализа данных МОГТ и КМПВ / Р.В. Белов, Н.И. Карапузов, В.А. Кондратов, В.П. Мельников // Геология нефти и газа. - 1990. - С. 33-36. URL: http://geolib.ru/OilGasGeo/1990/03/Stat/stat11.html (дата обращения 19.10.2018).

31. Белов Р.В. Переинтерпретация сейсморазведочных материалов по верхнепалеозойским залежам УВ юго-востока Западной Сибири // Геология нефти и газа. - 1992. - С. 5-8. URL: http://geolib.ru/OilGasGeo/1992/04/Stat/stat02.html (дата обращения 19.10.2018).

32. Конторович В.А. Тектоника и нефтегазоносность мезозойскокайнозойских отложений юго-восточных районов Западной Сибири / науч. ред. В.А. Сурков. - Новосибирск: Изд-во СО PАН. Фил. «ГЕ0», 2002. - 253 c. URL: https://xn-90ax2c. $\mathrm{xn}-\mathrm{p} 1 \mathrm{ai} / \mathrm{catalog} / 004971$ 000039_TUMNB-RU_EK_26. 325 \% D0 \% 9A65-087083/ (дата обращения 20.10.2018).

33. Litho-geophysical structure of Paleozoic-Mesozoic contact zonesin North-Ostaninsk oil field (Tomsk Oblast) / A. Ezhova, V. Merkulov, V. Chekanstev, R. Abramova // IOP Conf. Ser.: Earth Environ. Sci. - 2015. - № 24. - C. 1-8. URL: https://iopscience.iop.org/article/10.1088/1755-1315/24/1/012013 (дата обращения 20.10.2018).

34. Дубатолов В.Н., Краснов В.И. Палеобиогеография ЗападноСибирского моря в девонский период // Геология и геофизика. - 1993. - № 4. - С. 27-36.
35. Решения межведомственного совещания по рассмотрению и принятию региональной стратиграфической схемы палеозойских образований Западно-Сибирской равнины / под ред. В.И. Краснова. - Новосибирск: СНИИГГиМС, 1999. - 80 с.

36. Краснов В.И., Исаев Г.Д., Саев В.И. Новые данные по литостратиграфии палеозойских отложений юго-востока ЗападноСибирской плиты // Региональная стратиграфия нефтегазоносных районов. - Новосибирск: СНИИГГиМС, 1988. C. $9-13$.

37. Конторович А.Э. Первая отраслевая научно-исследовательская организация в области геологии нефти и газа в Сибири // Геология и минерально-сырьевые ресурсы Сибири. - Новосибирск: СНИИГГиМС, 2012. - № 1. - С. 5-15.

38. Shepherd T.J., Rankin A.H., Alderton D.H. A Practical Guide to Fluid Inclusion Studies. - 1985. - 239 c. - URL: https://www. researchgate.net/publication/279763895 A Practical Guide_to_Fluid_Inclusion_Studies (дата обращения 30.06.2018).

39. Ильичев И.С., Лазарев М.А., Щепалов А.А. Основы физикохимического анализа продуктов нефтепереработки и нефтехимического синтеза. - 2010. - 163 с. - URL: https://www. twirpx.com/file/494438/ (дата обращения 30.06.2018).

40. Jehlička J., Urban 0., Pokorný J. Raman spectroscopy of carbon and solid bitumens in sedimentary and metamorphic rocks // Spectrochimica Acta. Part A: Molecular and Biomolecular Spectroscopy. - 2003. - V. 59. - № 10. - P. 2341-2352. DOI: $10.1016 / \mathrm{s} 1386-1425(03) 00077-5$.

41. Diagenetic thermal evolution of organic matter by Raman spectroscopy / A. Schito, C. Romano, S. Corrado, D. Grigo, B. Poe // Organic Geochemistry. - 2017. - V. 106. - P. 57-67. DOI: 10.1016/j.orggeochem.2016.12.006.

42. Филиппов М.М. Рамановская спектроскопия как метод изучения глубоко углефицированного органического вещества. Ч. 1. Основные направления использования // Труды Карельского научного центра РАН. - 2014. - № 1. - Р. 115-134.

43. Li X., Hayashi J., Li C. FT-Raman spectroscopic study of the evolution of char structure during the pyrolysis of a Victorian brown coal // Fuel. - 2006. - V. 85. - № 12-13. - P. 1700-1707. DOI: 10.1016/j.fuel.2006.03.008.

44. Dennison J.R., Holtz M., Swain G. Raman spectroscopy of carbon materials // Spectroscopy. - 1996. - V. 11. - № 8. - P. 38-45.

45. Characterization of carbonaceous materials using Raman spectroscopy: a comparison of carbon nanotube filters, single- and multiwalled nanotubes, graphitised porous carbon and graphite / H.M. Heise, R. Kuckuk, A. Ojha K., A. Srivastava, V. Srivastava, B.P. Asthana // Journal of Raman Spectroscopy. - 2009. V. 40. - № 3. - P. 344-353. DOI: 10.1002/jrs.2120.

46. Wang Y., Alsmeyer D., McCreery R. Raman spectroscopy of carbon materials: structural basis of observed spectra // Journal Chemistry of Materials. - 1990. - V. 2. - № 5. - P. 557-563. DOI: $10.1021 / \mathrm{cm} 00011 \mathrm{a} 018$.

47. Rapid, direct and non-destructive assessment of fossil organic matter via microRaman spectroscopy / N. Ferralis, E.D. Matys, A.H. Knoll, C. Hallmann, R.E. Summons // Carbon. - 2016. V. 108. - P. 440-449. DOI: 10.1016/j.carbon.2016.07.039.

48. Raman spectral characteristics of magmatic-contact metamorphic coals from Huainan Coalfield, China / S. Chen, D. Wu, G. Liu, R. Sun // Spectrochimica Acta. Part A: Molecular and Biomolecular Spectroscopy. - 2017. - V. 171. - № 3. - P. 31-39. D0I: $10.1016 /$ j.saa.2016.07.032

49. A new approach to develop the Raman carbonaceous material geothermometer for low-grade metamorphism using peak width / Y. Kouketsu, T. Mizukami, H. Mori, S. Endo, M. Aoya, H. Hara, S. Wallis // Island Arc. - 2014. - V. 23. - № 1. - P. 33-50. DOI: 10.1111/iar.12057. 


\section{Информация об авторах}

Краснощекова Л.А., кандидат геолого-минералогических наук, доцент отделения геологии Инженерной школы природных ресурсов Национального исследовательского Томского политехнического университета.

Гарсия Бальса А.С., аспирант Инженерной школы природных ресурсов Национального исследовательского Томского политехнического университета.

Белозёров В.Б., доктор геолого-минералогических наук, заведующий лабораторией геологии Центра подготовки и переподготовки специалистов нефтегазового дела Инженерной школы природных ресурсов Национального исследовательского Томского политехнического университета. 


\title{
COMPOSITION OF FLUID INCLUSIONS BY RAMAN SPECTROSCOPY IN PALEOZOIC CARBONATE ROCKS OF SEVERO-OSTANINSK FIELD, WESTERN SIBERIA
}

\author{
Lyubov A. Krasnoshchekova', \\ krasnl@tpu.ru
}

\author{
Aura S. García', \\ garciaas@hw.tpu.ru \\ Vladimir B. Belozerov', \\ belozerovvb@hw.tpu.ru
National Research Tomsk Polytechnic University, 30, Lenin Avenue, Tomsk, 634050, Russia.

The relevance of the research is related to the possibility of detecting hydrocarbon deposits in the Paleozoic carbonate sediments of Western Siberia and increasing the oil and gas potential of the region.

The aim of the research is to determine the composition of gas-liquid inclusions in dolomitized carbonate rocks of Severo-Ostaninsk oil field using Raman spectroscopy, which will allow clarifying information on fluid composition and conditions of formation of secondary dolomites in limestone, due to their association with oil and gas accumulation zones.

The research object is the carbonate deposits in the roof part of the pre-Jurassic basement in Severo-Ostaninsk area of Western Siberia.

Methods: petrographic (crystal optics), Raman spectroscopy and UV photoluminescence analysis.

Results. The well section of the Severo-Ostaninsk field is composed of organogenic-oolitic limestone and dolomite of varying grain size. The petrographic study of carbonate rocks allowed distinguishing main phases of dolomitization in limestones: primary pelitomorphic material composing rock matrix together with calcite; secondary crystalline dolomite fulfilling fractures; and dolomite forming partially regular rhombohedral crystals. On a specific material, it was shown that using the Raman spectroscopy method, it was possible to detect in the gas-liquid inclusions of secondary dolomites spectral peaks at 1187, 1243, $1348 \mathrm{~cm}^{-1}$ typical of kerogen-containing organic matter, and peaks at 1525 and $1597 \mathrm{~cm}^{-1}$ characteristics of highly disordered carbon-containing material. The origin of these peaks are generated by $\mathrm{C}_{\text {aromatic }}-\mathrm{C}_{\text {alky }}$ vibrations; aromatic ethers, $\mathrm{C}-\mathrm{C}$ and $\mathrm{C}-\mathrm{H}$ in aromatic rings. The contribution from $\mathrm{C}=\mathrm{O}$ vibration was established as well. The presence of gas phases in the inclusions suggests that secondary dolomite in carbonate rocks was formed in the presence of carbonaceous matter dissolved in the rock-forming fluid.

Key words:

Raman spectroscopy, fluid inclusions, Pre-Jurassic carbonate rocks, dolomite, Western Siberia.

\section{REFERENCES}

1. Plechov P.Yu. Metody izucheniya flyuidnykh i rasplavnykh vklyucheny [Methods for studying fluid and melt inclusions]. Moscow, KDU Publ., 2014. 267 p.

2. Roedder E. Flyuidnye vklyucheniya v mineralakh [Fluid inclusions in minerals]. Priroda vklyucheniy i metody ikh issledovani$y a$ [The nature of inclusions and their research methods]. Translated from English. Moscow, Mir Publ., 1987. Vol. 1, 560 p.

3. Roedder E. Flyuidnye vklyucheniya v mineralakh [Fluid inclusions in minerals]. Ispolzovanie vklyucheniy pri izuchenii genezisa porod i rud [Use of inclusions when studying genesis of rocks and ores]. Translated from English. Moscow, Mir Publ., 1987. Vol. 2, $632 \mathrm{p}$.

4. Parnell J., Middleton D., Honghan C., Hall D. The use of integrated fluid inclusion studies in constraining oil charge history and reservoir compartmentation: examples from the Jeanne d'Arc Basin, offshore Newfoundland. Marine and Petroleum Geology, 2001, vol. 18, no. 5, pp. 535-549. D0I: 10.1016/s0264-8172(01)00018-6.

5. George S.C., Ruble T.E., Dutkiewicz A., Eadington P.J. Assessing the maturity of oil trapped in fluid inclusions using molecular geochemistry data and visually-determined fluorescence colours. Applied Geochemistry, 2001, vol. 16, no. 4, pp. 451-473. DOI: 10.1016/s0883-2927(00)00051-2.

6. Graney J.R., Kesler S.E. Factors affecting gas analysis of inclusion fluid by quadrupole mass spectrometry. Geochimica et Cosmochimica Acta, 1995, vol. 59, no. 19, pp. 3977-3986. DOI: 10.1016/0016-7037(95)00238-u.
7. Kurosawa M., Shimano S., Ishii S., Shima K., Kunihiro S., Kato T. Quantitative trace element analysis of single fluid inclusions by proton-induced X-ray emission (PIXE): application to fluid inclusions in hydrothermal quartz. Geochimica et Cosmochimica Acta, 2003, vol. 67, no. 22, pp. 4337-4352. D0I: 10.1016/S0016-7037(03)00378-8.

8. Wagner T., Fusswinkel T., Wälle M., Heinrich C. Microanalysis of fluid inclusions in crustal hydrothermal systems using laser ablation methods. Elements, 2016, vol. 12, no. 5, pp. 323-328. DOI: $10.2113 /$ gselements.12.5.323.

9. Richard A., Cauzid J., Cathelineau M., Boiron M. C., Mercadier J., Cuney M. Synchrotron XRF and XANES investigation of uranium speciation and element distribution in fluid inclusions from unconformity-related uranium deposits. Geofluids, 2012, vol. 13, no. 2, pp. 101-111. DOI: 10.1111/gfl.12009.

10. Williams A.E. Mass spectrometric analysis of volatiles in fluid inclusions: aliquot calibration valve to simulate inclusion rupture. Chemical Geology, 1996, vol. 131, no. 1-4, pp. 155-165. DOI: 10.1016/0009-2541(96)00064-2.

11. Pironon J., Barres 0. FT-IR Microanalysis of hydrocarbon fluid Inclusions. Geochemistry of the Earth's surface and of mineral formation 2nd International Symposium, France, 1990, pp. 224-226. DOI: org/10.1016/0009-2541(90)90220-2.

12. Pironon J., Thiery R., Ayt Ougougdal M., Teinturier S., Beaudoin G., Walgenwitz F. FT-IR measurements of petroleum fluid inclusions: methane, $\mathrm{n}$-alkanes and carbon dioxide quantitative analysis. Geofluids, 2001, vol. 1, no. 1, pp. 2-10. D0I: 10.1046/j.1468-8123.2001.11002.x. 
13. Kihle J. Adaptation of fluorescence excitation-emission microspectroscopy for characterization of single hydrocarbon fluid inclusions. Organic Geochemistry, 1995, vol. 23, no. 11-12, pp. 1029-1042. DOI: 10.1016/0146-6380(95)00091-7.

14. Wopenka, B., Pasteris J.D., Freeman J.J. Analysis of individual fluid inclusions by Fourier transform infrared and Raman microspectroscopy. Geochimica et Cosmochimica Acta, 1990, vol. 54, no. 3, pp. 519-533. DOI: 10.1016/0016-7037(90)90349-p.

15. Burke E.A. Raman microspectrometry of fluid inclusions. Lithos, 2001, vol. 55, no. $1-4$, pp. 139-158. DOI: $10.1016 / \mathrm{s} 0024-4937(00) 00043-8$.

16. Jehlička J., Edwards H.G. Raman spectroscopy as a tool for the non-destructive identification of organic minerals in the geological record. Organic Geochemistry, 2008, vol. 39, no. 4, pp. 371-386. DOI: 10.1016/j.orggeochem.2008.01.005.

17. Baludikay B., François C., Sforna M., Beghin J., Cornet Y., Storme J., Fagel N., Fontaine F., Littke R., Baudet D., Delvaux, Javaux E. Raman microspectroscopy, bitumen reflectance and illite crystallinity scale: comparison of different geothermometry methods on fossiliferous Proterozoic sedimentary basins (DR Congo, Mauritania and Australia). International Journal of Coal Geology, 2018, vol. 191, pp. 80-94. D0I: 10.1016/j.coal.2018.03.007

18. Sauerer B., Craddock P., Aljohani M., Alsamadony K., Abdallah W. Fast and accurate shale maturity determination by Raman spectroscopy measurement with minimal sample preparation. In ternational Journal of Coal Geology, 2017, vol. 173, pp. 150-157. DOI: $10.1016 /$ j.coal.2017.02.008

19. Khatibi S., Ostadhassan M., Aghajanpour A. Raman spectroscopy: an analytical tool for evaluating organic matter. Journal of Oil, Gas and Petrochemical Sciences, 2018, vol. 1, no. 1, pp. 28-33. DOI: 10.30881/jogps.00007

20. Toboka T. Raman spectroscopy of organic, solid and fluid inclusions in the Oldest Halite of LGOM area (SW Poland). Spectrochi mica Acta. Part A: Molecular and Biomolecular Spectroscopy, 2018, vol. 189, pp. 381-392. DOI: 10.1016/j.saa.2017.08.024

21. Bourdet J., Burruss R.C., Bodnar R.J., Eadington P.J. Asses sment of UV-Raman for analysis of petroleum inclusions. European Current Research on Fluid Inclusions (ECROFI-XXI). Austria, Montanuniversität Leoben, 2011. pp. 50-51.

22. Burke E.A., Lustenhouwer W.J. The application of a multichannel laser Raman microprobe (Microdil-28®) to the analysis of fluid inclusions. Chemical Geology, 1987, vol. 61, no. 1-4, pp. 11-17. DOI: 10.1016/0009-2541(87)90021-0.

23. Orange D., Kinitile E., Farber D., Williams Q. Raman spectroscopy of crude oils and hydrocarbon fluid inclusions: A feasibility study. Mineral Spectroscopy, 1996, vol. 5, no. 5, pp. 65-81. Available at: https://www.tib.eu/en/search/id/BLCP\% 3ACN024271905/ Raman-spectroscopy-of-crude-oils-and-hydrocarbon/ (accessed 18 October 2018).

24. Zhang N., Tian Z., Leng Y., Wang H., Song F., Meng J. Raman characteristics of hydrocarbon and hydrocarbon inclusions. Science in China Series D: Earth Sciences, 2007, vol. 50, no. 8, pp. 1171-1178. DOI: $10.1007 / \mathrm{s} 11430-007-0078-9$.

25. Verma D., Jadhav G.N., Biswal T.K., Jena S.K., Sharma N. Characterization of hydrocarbon-bearing fluid inclusion in sandstones of Jaisalmer basin, Rajasthan: a preliminary approach. Journal of the Geological Society of India, 2012, vol. 80, no. 4, pp. 505-514. DOI: 10.1007/s12594-012-0170-4.

26. Nandakumar V., Jayanthi J.L. Hydrocarbon fluid inclusions, API gravity of oil, signature fluorescence emissions and emission ratios: an example from Mumbai offshore, India. Energy \& Fuels, 2016, vol. 30, no. 5, pp. 3776-3782. D0I: 10.1021/acs.energyfuels.5b02952.

27. Jayanthi J.L., Nandakumar V., Anoop S.S. Feasibility of a $785 \mathrm{~nm}$ diode laser in Raman spectroscopy for characterizing hydrocarbon-bearing fluid inclusions in Mumbai Offshore Basin, In- dia. Petroleum Geoscience, 2017, vol. 23, no. 3, pp. 369-375. D0I: $10.1144 /$ petgeo2016-071.

28. Frezzotti M.L., Tecce F., Casagli A. Raman spectroscopy for fluid inclusion analysis. Journal of Geochemical Exploration, 2012, vol. 112, pp. 1-20. DOI: 10.1016/j.gexplo.2011.09.009.

29. Carey P.R. Raman Spectroscopy, the sleeping giant in structural biology, awakes. Journal of Biological Chemistry, 1999, vol. 274, no. 38, pp. 26625-26628. DOI: 10.1074/jbc.274.38.26625.

30. Belov R.V., Karapuzov N.I., Kondrashov V.A., Melnikov V.P. Experience in combined seismic facies analysis of CDPM and CMRW. Oil and gas geology, 1990, pp. 33-36. In Rus. Available at: http://geolib.ru/0ilGasGeo/1990/03/Stat/stat11.html (accessed 19 October 2018).

31. Belov R.V. Reinterpretation of seismic data on Upper Paleozoic hydrocarbon deposits in the southeastern part of Western Siberia. Oil and gas geology, 1992, pp. 5-8. In Rus. Available at: http://geolib.ru/OilGasGeo/1992/04/Stat/stat02.html (accessed 19 October 2018).

32. Kontorovich V.A. Tektonika i neftegazonosnost mezozoysko-kaynozoyskikh otlozheniy yugo vostochnykh rayonov Zapadnoy Sibiri [Tectonic and petroleum potential of the Mesozoic-Cenozoic sediments of the south-eastern regions of Western Siberia]. Scientific ed. V.A. Surkov. Novosibirsk, SB RAS. «GEO» Publ. house, 2002. 253 p. Available at: https://xn-90ax2c.xn-p1ai/cata$\log / 004971$ 000039_TUMNB-RU_EK_26.325_\% D0 \% 9A65-087083/ (accessed 20 0ctober 2018).

33. Ezhova A., Merkulov V., Chekanstev V., Abramova R. Litho-geophysical structure of Paleozoic-Mesozoic contact zonesin NorthOstaninsk oil field (Tomsk Oblast). IOP Conf. Ser.: Earth Environ. Sci, 2015, no. 24, pp. 1-8. Available at: https://iopscience.iop.org/article/10.1088/1755-1315/24/1/012013 (accessed 20 October 2018)

34. Dubatolov V.N., Krasnov V.I. Paleobiogeografiya Zapadno-Sibirskogo moray v devonskiy period [Paleobiogeography of the West Siberian Sea in the Devonian period]. Russian Geology and Geophisics, 1993, no. 4, pp. 27-36.

35. Resheniya mezhvedomstvennogo soveshchaniya po rassmotreniyu i prinyatiyu regionalnoy stratigraficheskoy skhemy paleozoyskikh obrazovaniy Zapadno-Sibirskoy ravniny [Decisions of interdepartmental meeting on the review and adoption of the regional stratigraphic scheme of the Paleozoic formations of the West Siberian Plain]. Ed. by V.I. Krasnov. Novosibirsk, SNIIGGIMS Publ., 1999.80 p.

36. Krasnov V.I., Isaev G.D, Saev V.I. Novye dannye po litostratigrafii paleozoyskikh otlozheniy yugo-vostoka Zapadno-Sibirskoy plity [New lithostratigraphy data on the Paleozoic deposits of the south-east of the West Siberian Plate]. Regionalnaya stratigrafiya neftegazonosnykh rayonov [Regional stratigraphy of oil and gas regions]. Novosibirsk, SNIIGGIMS Publ., 1988. pp. 9-13.

37. Kontorovich V.A. Pervaya otraslevaya nauchno-issledovatelskaya organizatsiya v oblasti geologii nefti i gaza v Sibiri [The first department research organization in the field of geology of oil and gas in Siberia]. Geologiya i mineralno-syrevye resursy Sibiri [Geology and mineral resources of Siberia]. Novosibirsk, SNIIGGIMS Publ., 2012. No. 1, pp. 5-15.

38. Shepherd T.J., Rankin A.H., Alderton D.H. A Practical Guide to Fluid Inclusion Studies. 1985.239 p. Available at: https://www.researchgate.net/publication/279763895 A Practical_Guide_to_Fluid_Inclusion_Studies (accessed 30 June 2018).

39. Ilichev I.S., Lazarev M.A., Shchepalov A.A. Fundamentals of physico-chemical analysis of refined petroleum products and petrochemical synthesis. 2010, 163 p. In Rus. Available at: https://www.twirpx.com/file/494438/ (accessed 30 June 2018).

40. Jehlička J., Urban 0., Pokorný J. Raman spectroscopy of carbon and solid bitumens in sedimentary and metamorphic rocks. Spectrochimica Acta. Part A: Molecular and Biomolecular Spectrosco- 
py, 2003, vol. 59, no. 10, pp. 2341-2352. DOI: $10.1016 / \mathrm{s} 1386-1425(03) 00077-5$.

41. Schito A., Romano C., Corrado S., Grigo D., Poe B. Diagenetic thermal evolution of organic matter by Raman spectroscopy. $\mathrm{Or}$ ganic Geochemistry, 2017, vol. 106, pp. 57-67. D0I: 10.1016/j.orggeochem.2016.12.006.

42. Filippov M.M. Ramanovskaya spektroskopiya kak metod izucheniya gluboko uglefitsirovannogo organicheskogo veshchestva. Ch. 1. Osnovnye napravleniya ispolzovaniya [Raman spectroscopy as a method for studying deeply carbonated organic matter. P. 1. The main directions of use]. Trudy Karelskogo nauchnogo tsentra RAN, 2014, no. 1, pp. 115-134.

43. Li X., Hayashi J., Li C. FT-Raman spectroscopic study of the evolution of char structure during the pyrolysis of a Victorian brown coal. Fuel, 2006, vol. 85 , no. 12-13, pp. 1700-1707. D0I: 10.1016/j.fuel.2006.03.008

44. Dennison J.R., Holtz M., Swain G. Raman spectroscopy of carbon materials. Spectroscopy, 1996, vol. 11, no. 8, pp. 38-45.

45. Heise H.M., Kuckuk R., Ojha A.K., Srivastava A., Srivastava V., Asthana B.P. Characterization of carbonaceous materials using Raman spectroscopy: a comparison of carbon nanotube filters, single- and multi-walled nanotubes, graphitised porous carbon and graphite. Journal of Raman Spectroscopy, 2009, vol. 40, no. 3, pp. 344-353. DOI: $10.1002 /$ jrs. 2120.

46. Wang Y., Alsmeyer D., McCreery R. Raman spectroscopy of carbon materials: structural basis of observed spectra. Journal Chemistry of Materials, 1990, vol. 2, no. 5, pp. 557-563. DOI: 10.1021/cm00011a018.

47. Ferralis N., Matys E.D., Knoll A.H., Hallmann C., Summons R.E. Rapid, direct and non-destructive assessment of fossil organic matter via microRaman spectroscopy. Carbon, 2016, vol. 108, pp. 440-449. DOI: 10.1016/j.carbon.2016.07.039.

48. Chen S., Wu D., Liu G., Sun R. Raman spectral characteristics of magmatic-contact metamorphic coals from Huainan Coalfield, China. Spectrochimica Acta. Part A: Molecular and Biomolecular Spectroscopy, 2017, vol. 171, no. 3, pp. 31-39. DOI: $10.1016 /$ j.saa.2016.07.032.

49. Kouketsu Y., Mizukami T., Mori H., Endo S., Aoya M., Hara H., Wallis S. A new approach to develop the Raman carbonaceous material geothermometer for low-grade metamorphism using peak width. Island Arc, 2014, vol. 23, no. 1, pp. 33-50. DOI: 10.1111/iar.12057.

Received: 8 February 2019.

\section{Information about the authors}

Lyubov A. Krasnoshchekova, Cand. Sc., associate professor, National Research Tomsk Polytechnic University.

Aura S. García, postgraduate student, National Research Tomsk Polytechnic University.

Vladimir B. Belozerov, Dr. Sc., professor, National Research Tomsk Polytechnic University. 